International Journal of Engineering \& Technology, $7([2.29)(2018) 429-435$
SPC
Website www.sciencepubco.com/index.php/IJET
Research paper

\title{
Relationship Between Distributive Justice, Ethical Leadership, and Turnover Intention with the Mediating Effects of Ethical Climate
}

\author{
Nasir Mehmood ${ }^{1 *}$, Dr. Ungku Norulkamar², Dr. Saman Attiq ${ }^{3}$, Sobia Irum ${ }^{4}$ \\ ${ }^{1}$ Faculty Of Management Sciences, Universiti Teknologi Malaysia (UTM), Johor, Malaysia \\ ${ }^{2}$ Faculty Of Management Sciences, Universiti Teknologi Malaysia (UTM), Johor, Malaysia \\ ${ }^{3}$ Faculty Of Management Sciences, University of Wah, Pakistan \\ ${ }^{4}$ Faculty Of Management Sciences, Universiti Teknologi Malaysia (UTM), Johor, Malaysia \\ *Corresponding Author E-Mail: Inasirpk@Hotmail.Com
}

\begin{abstract}
Leaders form an organization's ethical climate and influence employees' perceptions and intentions. Employees' intentions become positive when leader's personal ethics and ethical climate are congruent. The current study focused on the relationships among ethical leadership, distributive justice and ethical climate in the formation of employee's turnover intention. The purpose of the study is (1) to examine whether leader's ethics significantly impact over turnover intention, (2) to what extent distributive justice effects turnover intention, and (3) to determine the indirect impact of ethical leadership on turnover intention through ethical climate. The valid sample data was randomly collected through structured questionnaire distributed among 265 employees from 9 different banks located in Northern Punjab region of Pakistan. Structural equation modeling (SEM) was used for data analysis using AMOS 22.0. Results revealed that distributive justice is significantly related to turnover intentions and ethical climate mediated between ethical leadership and turnover intention. This study contributes to the existing literature by considering both, distributive justice and ethical leadership in predicting turnover intention. When enacting policies and procedures, leaders should set ethical and justice tone that can be helpful to facilitate ethical behavior and also minimize turnover intentions among employee
\end{abstract}

Keywords: Distributive Justice; Ethical Leadership; Ethical Climate; Turnover Intention

\section{Introduction}

Management of Human capital is a big challenge and is a global issue as it is becoming increasingly difficult for most organizations to retain their competent employees. According to a study (Holtom, Mitchell, Lee, \& Inderrieden, 2005), strategic importance of human capital and the cost associated with turnover of competent employees have compelled companies to concentrate over turnover challenge. Turnover intention is described as an employee's inclination to quitting organization (Tett \& Meyer, 1993) and is potentially a threat to organization's competitiveness if competent employees tend to leave organization. Banking industry, just like any other industry, is also facing a serious issues in retaining its competent human resource. If strategies and policies for retaining competent employees are not developed, the banking industry may eventually become unstable and insubstantial (Yin-Fah, Foon, Chee-Leong, \& Osman, 2010). Hence coping with the problem of increasing rate of employee turnover is strategically very important for the banking industry and should find ways to motivate the employees to remain with the organization. According to a recent survey statistics report, in the last 6 years between 2011 and 2016, turnover intentions in different industries including banking and finance industry has shown considerable increase (CompData, 2015-16). In this survey of more than 30,000 organizations worldwide in different industries, banking and finance sector worldwide has been reported with a significant in- crease in employee turnover from $14.4 \%$ in 2011 to $17.8 \%$ in 2016. Another survey on human capital trends by Deloitte University Press in 2014 conducted in 20,000 organizations from different industries worldwide including banking and finance sector reported that $83 \%$ financial organizations have reported that the second highest human resource management challenge is "employee retention and employee engagement" that needs attention on priority basis.

Keeping in view the recently reported issues of increasing employee turnover in financial sector (CompData, 2015-16) and the cost of service quality associated with competent employees leaving organization (Hunjra, Chani, Aslam, Azam, \& Rehman, 2010), it has become imperative to conduct further empirical investigation into the turnover phenomenon. Although, there are number of studies that have previously studied turnover issues in financial sector in different regional and organizational settings (Bakri \& Ali, 2015; Hassan, 2002), however it has been recently reported that turnover rate is increasing gradually in Pakistani banking industry (Asrar-ul-Haq \& Kuchinke, 2016; Bilal, Rehman, \& Rehman, 2015) and it is becoming competitive due to influx of private and international banking organizations in the local industry (Bilal et al., 2015; Bodla \& Ali, 2012; Ramay, 2012). Consequently, bank employees are finding more lucrative job opportunities to capitalize on by switching over to the banks who are offering better rewards and incentive (pays, promotions, positions, 
career opportunities etc.) and conducive work environment (leadership and organizational support). Thus, the present study realized a need to empirically examine the fact that to what extent fairness in rewards allocation (distributive justice) and a fair work environment (ethical leadership and ethical climate) can effect employee turnover intention.

Justice climate and ethical climate are two of the predominant factors that have been researched in the social sciences and management literature. Researchers have recently developed an integrated model of justice and ethical climates to predict employee's attitudes and behaviors (Macklin, Martin, \& Mathison, 2014). They suggested that both organizational justice and ethical management are significant factors that may influence perceived fairness among organizational procedures and decision outcomes. Moreover, it has also been recently suggested that there is direct association between ethical leadership and turnover intentions among employees (DeConinck, 2015). The employees or followers are tend to generate more positive and quality association with the leaders who are perceived just and honest (Brown \& Treviño, 2006). According to (2005), followers when treated fairly (organizational justice) and ethically, show their gratitude towards their leaders by responding with positive attitudes and a stronger interpersonal relationship. Thus, organizational justice in terms of fair rewards allocation (distributive justice) and ethical leadership are the predominant organizational factors that may influence employee's intentions to stay longer with the organization and reduce their turnover intentions.

Theory of Social Learning (Bandura, 1977) explained that organizational leaders play a critical and influential role to determine employees' positive attitudes and behaviors. (2012) described ethical leadership as a process in which leaders influence their employees through their values, beliefs and principles based on acceptable standards in the organizational behaviors. According to (2007), ethical leadership has been generally described on the basis of normative terms of leadership which emphasis that the leadership style and ethical decision making should be based on moral and principle based conduct of leaders. Ethical leaders encourage honesty and perform those actions which reflect their beliefs and values. Nevertheless, (2005) described that ethical leaders exhibit and promote appropriate behavior to motivate their followers through effective communication, personal conduct and interpersonal relationship. The present study promotes and supports the same idea that in the social learning process, the leader's ethically based decisions and personal moral standing has a great significant influence on the intentions and perceptions of the employees about the fairness process. Thus, Ethical leadership is considered as an important predictor of behavioral and attitudinal outcomes such as turnover intention.

Another factor that is considered critical for predicting employees' intentions and attitudes such as turnover intention is distributive justice. Distributive justice is explained as perceived fairness in rewards and resource allocation (Niehoff \& Moorman, 1993) based on the theory of equity (Adams, 1965). The equity theory reinforces the idea that fairness in rewards must be carried to justify that individual's rewards (such as pays and incentives) are equitable with their work efforts. If distributive justice is not perceived by the employees, it is likely to influence interpersonal associations between employees and organizational representatives which may consequently generate negative outcomes (Al Afari \& Elanain, 2014). Thus, distributive justice has the tendency to direct individual's perceptions and attitudes based on associations. For example, perceived injustice in distribution of rewards and opportunities can develop an imbalance of input and output which may damage accomplishment of organizational objectives and eventually turn into negative attitude such as turnover intention.
To what extent distributive justice, ethical leadership, and ethical climate determine turnover intention.

To examine the impact of distributive justice on turnover intention.

To investigate effect of ethical leadership over turnover intention

To examine whether ethical climate mediates between ethical leadership and turnover intention.

\section{Literature Review}

\subsection{Distributive Justice And Turnover Intention}

Predominantly, past studies showed a negative relationship between distributive justice and turnover intention. (2012) conducted his study on 168 employees of different organizations studying MBA in five different Malaysian universities. According to a study, distributive justice and turnover intentions are negative associated with each other (Poon, 2012). Previously, the study by (2002) which was conducted on 171 employees of Banks and other companies, also reported distributive justice can significantly reduce employee turnover intentions. Moreover, a study conducted by Loi, Hang-Yue, and Foley (2006) also revealed that perceptions in terms of fairness in rewards received and turnover intentions are significantly and negatively correlated. A recent study (Khan, Abbas, Gul, \& Raja, 2013) exhibited a negative correlation between distributive justice and turnover intentions when low Islamic work ethics are perceived.

These studies empirically examined distributive justice to predict turnover intentions in the context of different organizational, regional and cultural settings. While fairness in rewards allocation is observed in terms of monetary outcomes such as salary, increments and other tangible incentives. Moreover the study of (1993) showed that distributive justice also promotes the fairness in allocating tangible, intangible and other outcomes such as work load, work schedules and job responsibilities. The outcomes are important and can effect turnover intentions of employees. A recent study of (2015) conducted with a smaller sample size (177) from commercial banking sector in Pakistan reported a significantly negative association between distributive justice and turnover intentions. However, a more comprehensive study is needed in the banking sector of Pakistan. Thus it is hypothesized that:

H1: There is direct and negative relationship between distributive justice and turnover intention.

\subsection{Ethical Leadership And Turnover Intention}

Gaining employee's trust and motivating them to exhibit positive attitudes towards decision outcomes can be possible by ensuring a fair treatment by the leader as a decision maker. The fair treatment can translate leader's behavior into ethical perceptions of the employees. According to (2015) carried a study on sales representatives and found that ethical leadership has a direct impact on staff turnover intentions. Moreover, there is always a high quality interpersonal relationship and behavior exist between ethical leaders and their followers (2005). Moreover, followers feel obliged to respond positively with a stronger interpersonal connections when they are treated fairly (organizational justice) and ethically (Brown et al., 2005). (2012) collected data through a large sample (1093) of 70 organizations from nine different industries and found perceived ethical leadership negatively correlated with turnover intentions. (2012) further concluded that the employee's turnover intentions can be significantly influenced by their perceptions about ethical leadership. Thus, it is hypothesized that: 
$\mathrm{H} 2$ : There is direct and negative relationship between ethical leadership and turnover intention.

\subsection{Ethical Leadership And Ethical Climate}

The construct of ethical leadership in the literature emerged on the basis of general issues emanated within from the leadership research. Predominantly, the concept of ethical leadership advocates the basis of honesty and integrity (Kuntz, Kuntz, Elenkov, \& Nabirukhina, 2013). Similarly, it has also been argued that personal morals, credibility, and honesty are basis of ethical leadership (Eubanks, Brown, \& Ybema, 2012). Ethical leadership mirrors the elements of organizational leadership, behavior and culture with the essential part of making so as to drive the ethical decisions innately effecting employees' attitudes and communications (Alshammari, Almutairi, \& Thuwaini, 2015). It has been empirically demonstrated that the leadership abilities take the credit for increasing business competencies in the contemporary business environment. The importance of ethical leadership spins around the pragmatic business practices that are strongly linked with cultural and ethical elements. Ethical leadership is further characterized as the process of influencing subordinates through values, principles and beliefs that widely verge on the acknowledged standards of organizational behaviors (Buble, 2012). Ethical Leadership is considered to be the standout factor amongst the most significant precursors of the ethical climate.

A considerable amount of business ethics research has converged on ethical climate as an essential predecessor of organizational consequences (Shin, 2012) and in this manner, it has turned out to be evident that development of strong corporate ethical climate is key to anticipate unethical behavior (Ahmed \& Machold, 2004) Thus, the organizational ethical climate is generally described as a shared perception of ethically correct behavior and the way ethical issues are dealt in the organization (Peterson, 2002). Previous studies on ethical leadership has additionally focused on its association with organizational consequences. For instance, (Brown et al., 2005) argued, based on empirical evidence, that ethical leadership is unequivocally connected to its followers' satisfaction with their leaders, extra efforts applied at work, and willingness to report problems.

A work climate may be described as psychologically perceived significant moral attitudes at workplace (Schneider, 1975). However, a number of different climates may prevail in an organization. Ethical climate is overwhelmingly perceived as the combinations of methodology and practices adopted by the organization that are generally considered ethical and substantial (Victor \& Cullen, 1988). Although, a leader's moral conduct is an important driver to build up an ethical organization but it may not be sufficient. Manager and supervisors, being the ethical leaders, should act as agents of righteous behavior in order to advance ethical climate (Flynn, 2008).

Recently, (Demirtas \& Akdogan, 2015) investigated different employees involving managers and technical staff from various organizations and found that ethical leadership plays a critical and significant role in developing ethical climate. At the point when workplace behaviors are seen to be ethically correct, the employees' perceptions effect their ethical decision-making and attitudes toward their jobs (Brown \& Treviño, 2006). The aggregate impact of overall ethical perceptions among organizational members create a workplace that is recognized by shared ethical work standards (Davidovitz et al., 2007; Dickson et al., 2001). In other works, employee's attitude towards job and organization is influenced by prevailing ethical climate in the organization (Cullen et al., 2003). Thus the present study hypothesized that:

H3: There is direct and positive relationship between ethical leadership and ethical climate.

\subsection{Ethical Climate As A Mediator}

Ethical Climate is defined as "prevailing perceptions of typical organizational practices and procedures that have ethical content" (Victor \& Cullen, 1988). The stronger sense of moral responsibility among employees reflects their ability to identify what morally and ethically correct behaviors are which can be reasonably credited to the existing ethical climate maintained by the organization. More recently the notion of ethical climate as a contextual factor has been described as employees being aware of their moral obligations (Wang \& Hsieh, 2012). Unethical behaviors are triggered by the ignorance of the organization in developing and implementing codes of ethics, policies and procedures that discourage, monitor, and rectify employees' unethical and immoral behaviors (Ferrell \& Gresham, 1985). Organizational decision making, in general and at all levels, must be supported by a strong rationale implying ethical reasoning which can be clearly traced back in prescribed codes of ethics.

Behavioral aspect of ethical leadership is also an important consideration in ethical literature. Since the ethical leadership deals with ethical decision making regarding employees' it has been found positively related to ethical climate development (Leventhal, 1980; Newman, 1993). The ethical leadership and ethical climate both are the contextual factors that concentrate on almost similar behavioral outcomes but surprisingly previous research lacks the consistency in investigating the relationship between the two. For example both leadership and ethics target to reduce counterproductive behaviors (like cheating, stealing, abusing, sabotage etc.) at workplace. Ethical leadership and management is perceived to be the role model for establishing organizational ethical norms and therefore every decision taken by the management. Thus, the supervisors and managers being leaders and decision makers have to play a critical and active role in creating, inculcating moral values and nourishing ethical climate among employees (Brown et al., 2005; Flynn, 2008). Consequently, ethical climate creates a sense of fairness in organizational treatment and develop positive responses (Brown \& Treviño, 2006).

Past empirical research has explored the ethical climate, ethical leadership behaviors, and their connections with antecedents and outcomes in hospitality industry (Kim \& Brymer, 2011) and banking industry (Küçükbayrak, 2010). More recently (2015) conducted an empirical study among different professionals and managers to investigate the indirect effect of ethical leadership over turnover intention through ethical climate. They found that ethical leadership is a strong determinant employees' turnover intention through ethical climate and consequently increases their emotional association to remain with the organization for longer time. However, a further empirical research in this regard is required in the banking sector. The present research study examines the influence that ethical leadership behavior has on turnover intention by the way of ethical climate among employees in Pakistani banks. Thus it is hypothesized that:

H4: Ethical climate acts as mediator between ethical leadership and turnover intention.

\subsection{Conceptual Framework Of The Study}

This study is a correlational study which is intended to investigate the relationship between Ethical leadership (independent variables) and turnover intention (dependent variable) while taking Ethical climate as a Mediating variable. Ethical climate is explained as the organizational culture or factors that promote the moral and ethical values within organizational environment and its members.

Direct relation of Distributive Justice is also investigated. Distributive justice is explained as the fairness in rewards allocation pro- 
cedures. The initial argument on distributive justice is linked to the equity theory (Adams, 1965). The literature provides a strong argument that attitudinal factor like turnover intention is strongly affected by organizational factors like distributive justice.

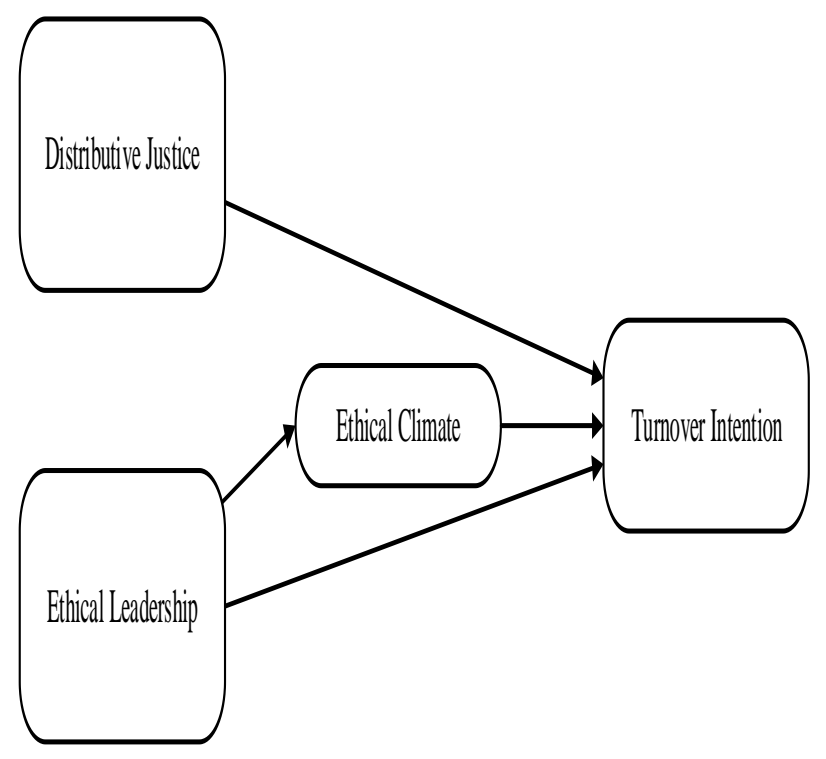

Fig 1. Conceptual framework

\section{Methodology}

The research design of the study is descriptive which tends to investigate the associations between the dependent and independent variables. According to ${ }^{4545}$, descriptive research is suitable for investigating relationships among variables. The present study used a personally administered survey through a structured questionnaire distributed among targeted respondents to collect data. Surveys are considered as appropriate and economical data collection method depending upon the availability of time and budget (Alreck \& Settle, 2004).

\subsection{Population and Sampling}

Population consisted of Islamic banks in Pakistan. A total of 330 bank employees were selected as sample size for the present study. Targeted respondents were provided with briefing by the researchers in the form of personal discussions. It is expected that all of the respondents have given the response correctly and honestly up to their understanding of the questionnaire and briefing. All the questionnaires were returned by the respondents. However, a total 55 survey questionnaires were incomplete, hence excluded from the study. Thus, the response rate was determined at $83 \%$ $(265 / 330)$.

\subsection{Measures}

The present study included four research instruments. Each variable was measured through a separate set of questions included in the survey questionnaire. Distributive Justice (i.e. Independent Variable) measure was developed by (2001) containing 5-items and examined through a 5-point Likert Scale ranging from ' 1 ' for 'to a very small extent' to ' 5 - to a very large extent'. (2005) developed 10-items ethical leadership scale and found to be validated, which is adopted for this study. A sample item is "My supervisor listens to what employees have to say". Turnover Intention (i.e. dependent variable) was measured through a 5-point liker scale adopted from (Tett \& Meyer, 1993).
Moreover, data was analyzed through a commonly used research software of SPSS and AMOS for structural equation modeling (SEM). Pearson correlation coefficient is used to measure the strength of relationship between variables. The mediation effect is measured through path analysis values of both direct and indirect relationships between independent variables (i.e. Distributive justice and Ethical leadership) and dependent variable (i.e. Turnover intention) and mediating variable (i.e. Ethical climate).

\section{Results and Findings}

Sample have more male respondents $(148,55.8 \%)$ than female $(117,44.2 \%)$. Total 161 respondents lie in below 25 -years age group, $115(43.4 \%)$ respondents have above 18-Years qualification. $133(50.2 \%)$ employees have more than 10 years' work experience. (See Table-1)

Table-1 Sample Descriptive $(\mathrm{N}=265)$

\begin{tabular}{|c|c|c|c|c|c|c|c|}
\hline $\begin{array}{l}\text { Demo- } \\
\text { graphic } \\
\text { Variables }\end{array}$ & Codes & $\begin{array}{l}\text { Fre- } \\
\text { quen } \\
\text { cy }\end{array}$ & $\begin{array}{l}\% \\
\text { Total } \\
\text { Sam } \\
\text { ple }\end{array}$ & $\begin{array}{l}\text { Mean/ } \\
\text { (Mode) }\end{array}$ & S. D & $\begin{array}{l}\text { Ske } \\
\text { wnes } \\
\text { s }\end{array}$ & $\begin{array}{l}\text { Kur } \\
\text { to- } \\
\text { sis }\end{array}$ \\
\hline \multirow{2}{*}{ Gender } & 1).Female & 117 & 44.2 & \multirow{2}{*}{ 2(mode } & \multirow{2}{*}{0.50} & \multirow{2}{*}{-0.24} & \multirow{2}{*}{$\begin{array}{l}- \\
1.9 \\
6\end{array}$} \\
\hline & 2). Male & 148 & 55.8 & & & & \\
\hline \multirow{3}{*}{$\begin{array}{l}\text { Age } \\
\text { (In years) }\end{array}$} & $\begin{array}{ll}\text { 1). } & \text { Below } \\
30 & \\
\end{array}$ & 42 & 15.8 & \multirow{3}{*}{1.95} & \multirow{3}{*}{0.52} & \multirow{3}{*}{-.07} & \multirow{3}{*}{$\begin{array}{l}0.7 \\
5\end{array}$} \\
\hline & 2). $30-40$ & 194 & 73.2 & & & & \\
\hline & $\begin{array}{ll}\text { 3). Above } \\
40\end{array}$ & 29 & 10.9 & & & & \\
\hline \multirow{3}{*}{$\begin{array}{l}\text { Qualifi- } \\
\text { cation }\end{array}$} & $\begin{array}{l}\text { 1). Bache- } \\
\text { lor }\end{array}$ & 3 & 1.1 & \multirow{3}{*}{2.54} & \multirow{3}{*}{0.52} & \multirow{3}{*}{-0.42} & \multirow{3}{*}{$\begin{array}{l}- \\
1.3 \\
0\end{array}$} \\
\hline & 2). Masters & 115 & 43.4 & & & & \\
\hline & $\begin{array}{l}\text { 3). Above } \\
\text { Masters }\end{array}$ & 147 & 55.5 & & & & \\
\hline \multirow{3}{*}{$\begin{array}{l}\text { Experi- } \\
\text { ence } \\
\text { (in years) }\end{array}$} & $\begin{array}{ll}\text { 1). } & \text { Below } \\
10 & \\
\end{array}$ & 80 & 30.2 & \multirow{3}{*}{1.89} & \multirow{3}{*}{0.70} & \multirow{3}{*}{0.15} & \multirow{3}{*}{$\begin{array}{l}- \\
0.9 \\
4\end{array}$} \\
\hline & 2). $10-20$ & 133 & 50.2 & & & & \\
\hline & $\begin{array}{l}\text { 3). Above } \\
20\end{array}$ & 52 & 19.6 & & & & \\
\hline
\end{tabular}

\subsection{Correlation Analysis and Descriptive of Variables}

For checking association among variables, correlation analysis was used. Results showed significant association among all variables (i.e. $\mathrm{p}<0.01$ ). Correlation results showed strong positive correlation among distributive justice and ethical climate $(r=0.75)$. While distributive justice and turnover intentions have strong negative association $(r=-0.70)$. In the same way, ethical leadership and turnover intentions have strong negative association $(r=-0.75)$ (see Table-2).

Table-2 Correlation Analysis and Descriptive Statistics of Latent Variables

\begin{tabular}{|c|c|c|c|c|c|c|c|}
\hline $\begin{array}{c}\text { Latent Vari- } \\
\text { ables }\end{array}$ & 1 & 2 & 3 & 4 & $\begin{array}{l}\text { Mean } \\
\text { (S.D) }\end{array}$ & $\begin{array}{c}\text { Skew- } \\
\text { ness }\end{array}$ & $\begin{array}{l}\text { Kurto- } \\
\text { sis }\end{array}$ \\
\hline $\begin{array}{l}\text { 1.Distributiv } \\
\text { e Justice }\end{array}$ & 1 & & & & $\begin{array}{c}3.22 \\
(0.73 \\
)\end{array}$ & -0.37 & -1.14 \\
\hline $\begin{array}{l}\text { 2.Ethical } \\
\text { Leadership }\end{array}$ & $\begin{array}{c}0.7 \\
8\end{array}$ & 1 & & & $\begin{array}{c}3.04 \\
(0.66 \\
)\end{array}$ & -.37 & -1.05 \\
\hline $\begin{array}{l}\text { 3.Ethical } \\
\text { Climate }\end{array}$ & $\begin{array}{c}0.6 \\
3\end{array}$ & $\begin{array}{c}0.6 \\
8\end{array}$ & 1 & & $\begin{array}{c}2.91 \\
(0.50 \\
)\end{array}$ & -0.28 & -0.77 \\
\hline $\begin{array}{l}\text { 4.Turnover } \\
\text { Intentions }\end{array}$ & $\begin{array}{c}- \\
0.5 \\
7\end{array}$ & $\begin{array}{c}- \\
0.5 \\
8\end{array}$ & $\begin{array}{c}- \\
0.6 \\
1\end{array}$ & 1 & $\begin{array}{c}2.65 \\
(0.66 \\
)\end{array}$ & 0.61 & 0.16 \\
\hline
\end{tabular}

Descriptive statistics of latent constructs were also checked as mean value lie between 2.71 to 3.16 . While std. deviation lie between $0.55-0.74$. For checking normality, skewness and kurtosis 
were also measured. Their values lie between the acceptable ranges from -2 to +2 (See Table-2).

\subsection{Structural Equation Modeling (SEM)}

\subsubsection{Testing of Measurement Model}

For measurement model, confirmatory factor analysis was executed. This analysis helps to judge the hypotheses relating to factor structure and to check the consistency with observed date. CFA analysis consisted on two measures i.e. squared multiple correlations (SMC) and factor loading (FL) for both observed and unobserved/latent constructs. Factor loading (i.e. standardized regression weights) explain relation among latent constructs and their indicators. While, SMC is known as lower bound estimates of reliability and explain proportion of variance that is accounted for by its indicators (Hu \& Bentler, 1999). SMC of variables represent the reliability of all observed variables and it is like the square of the FL of an exploratory factorial analysis.

Factor loading (FL) and squared-multiple-correlation (SMC) values measured to study reliability of items and observed errors. If FL value of an item is less than 0.50 and SMC value is less than 0.20 then this item is excluded as per standard of $(\mathrm{Hu} \&$ Bentler, 1999). For measurement model, first latent variable was distributive justice (DJUS) and its items have FL and SMC values among $0.66-0.83$ and $0.43-0.69$ respectively. Only one item was deleted due to low FL and SMC values. Second latent variable was ethical leadership (TEL) and its items have FL and SMC values among 0.70-0.74 and 0.49-0.54 respectively. However only two items were deleted due to low FL and SMC values. Third latent variable was ethical climate (TEC) and its items have FL and SMC values among $0.59-0.75$ and $0.35-0.56$ respectively. Similarly, only 2 items were deleted due to low FL and SMC values. Fourth latent variable was turnover intention (TINT) and its items have FL and SMC values among 0.60-0.69 and 0.36-0.48 respectively.

Table-3 Results of Measurement Model

\begin{tabular}{|l|c|c|c|c|c|}
\hline $\begin{array}{l}\text { Latent Vari- } \\
\text { ables }\end{array}$ & $\begin{array}{c}\text { SMC } \\
\text { Range }\end{array}$ & $\begin{array}{c}\text { St. FL } \\
\text { Range }\end{array}$ & $\begin{array}{c}\text { Cronb } \\
\text { ach } \\
\text { Alpha }\end{array}$ & CR & AVE \\
\hline $\begin{array}{l}\text { 1. Distribu- } \\
\text { tive Justice }\end{array}$ & $0.43-0.69$ & $0.66-0.83$ & 0.84 & 0.84 & 0.56 \\
\hline $\begin{array}{l}\text { 2. Ethical } \\
\text { Leadership }\end{array}$ & $0.49-0.54$ & $0.70-0.74$ & 0.89 & 0.89 & 0.51 \\
\hline $\begin{array}{l}\text { 3. Ethical } \\
\text { Climate }\end{array}$ & $0.35-0.56$ & $0.59-0.75$ & 0.73 & 0.86 & 0.46 \\
\hline $\begin{array}{l}\text { 4. Turnover } \\
\text { Intention }\end{array}$ & $0.36-0.48$ & $0.60-0.70$ & 0.74 & 0.73 & 0.51 \\
\hline
\end{tabular}

Structural model has 4 latent variables with twenty-three observed variables. Conceptual model have 2 exogenous variables i.e. distributive justice (TDJ) and ethical leadership (TEL) and 2 endogenous variables i.e. ethical climate (TEC) and turnover intentions (TINT).

\subsection{Hypotheses Testing}

\subsubsection{Direct Effect}

$\mathrm{H}_{1}$ : There is direct and negative relationship between distributive justice and turnover intention.

According to the first hypothesis i.e. $\mathrm{H}_{3}$, the value of standardized regression $\left(\mathrm{H}_{2}: \gamma=-0.15, \mathrm{p}<0.05\right)$ indicated that distributive justice and turnover intention have significant negative relationship.

$\mathrm{H}_{2}$ : There is direct and negative relationship between ethical leadership and turnover intention. 
According to the second hypothesis i.e. H4, the value of standardized regression $(\mathrm{H} 4: \gamma=-0.11, \mathrm{p}>0.05)$ indicated that ethical leadership and turnover intention have insignificant relationship.

$\mathrm{H}_{3}$ : There is direct and positive relationship between ethical leadership and ethical climate.

According to the fourth hypothesis i.e. $\mathrm{H}_{4}$, the value of standardized regression $\left(\mathrm{H}_{1}: \gamma=0.79, \mathrm{p}<0.05\right)$ indicated that ethical leadership and ethical climate have significant positive relationship.

At end, goodness fit indices of structural model also tested that presented satisfactory results i.e. $\mathrm{CMIN} / \mathrm{DF}=2.98$; $\mathrm{GFI}=0.89$; $\mathrm{AGFI}=0.80 ; \mathrm{CFI}=0.90 ;$ RMSEA $=0.08$.

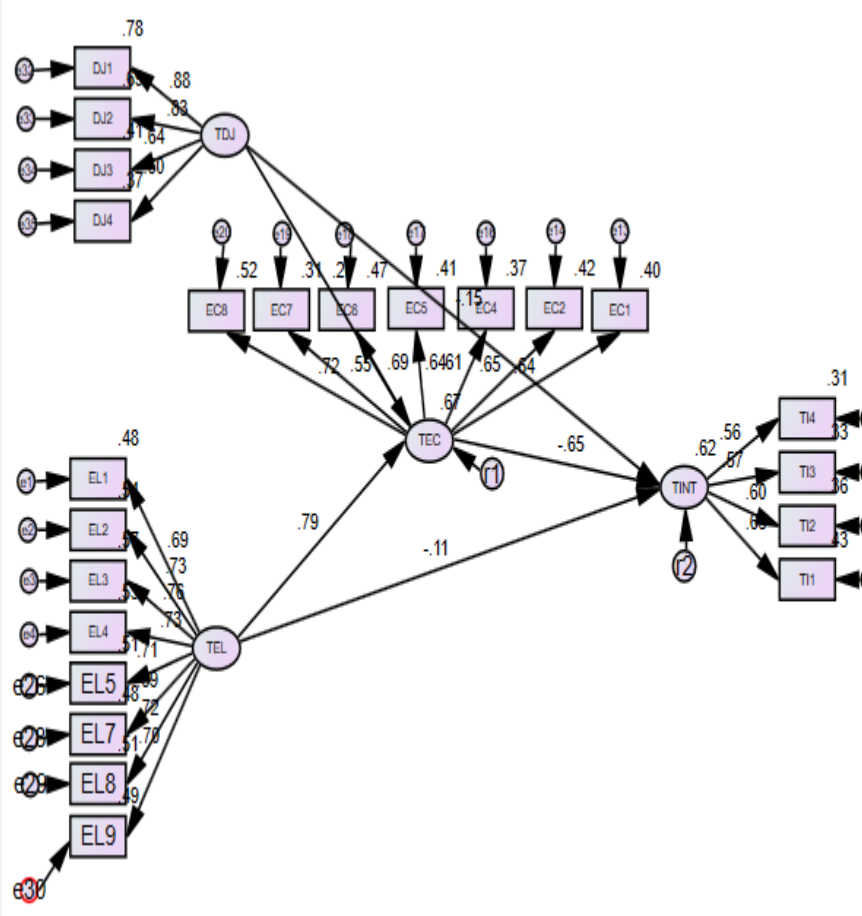

Fig3.2. Structural Model

\subsubsection{Indirect Effect}

$\mathrm{H}_{4}$ : Ethical climate acts as mediator between ethical leadership and turnover intention.

To find out mediation effect hypothesized in $\mathrm{H}_{6}$, mediation analysis was performed using bootstrapping with biased correlated confidence estimate. Indirect effect was computed with 5000 bootstrapping at $95 \%$ biased correlated confidence. Indirect effect of ethical leadership over turnover intention was -0.52 and standard error was 0.08 with $\mathrm{p}<0.05$ which showed that ethical climate acts as a mediator between ethical leadership and turnover intention.

\section{Conclusions}

The objective of this study is to investigate the relationship of distributive justice and ethical leadership with turnover intention along with a mediating role of ethical climate among nonmanagerial staff employed in commercial banks of Pakistan. The findings revealed that distributive justice has a significant negative relationship with turnover intention which supported the empirical findings of recent studies (Ali \& Saifullah, 2014; Bakri \& Ali, 2015). The employees in Pakistani banks consider distributive justice as one of the major determinant of their turnover intention.
According to (1993) and (1980), ethical leadership positively effects ethical climate. The notion of ethical climate is described as employees being aware of their moral obligations (Wang \& Hsieh, 2012). Furthermore, (1985) argued that unethical behavior of leader reflect organizational ignorance in developing and implementing codes of ethics, policies and procedures that discourage, monitor, and rectify employees' behaviors. However, ethical climate fully mediated between ethical leadership and turnover intention which reflects the importance of ethical environment to drive moral conduct of employees in the organizations. In other words, employees; intention to quit is contingent to both distributive fairness in terms of both allocation of rewards and perceived moral values prevailing in the overall organizational environment and ethical style of leadership as well.

According to (Treviño \& Weaver, 2001), failing to maintain ethical standards is perceived as predictor of stressful work environment which may consequently compel employees to look for alternative job opportunities in other organizations. Thus, ethical climate can significantly influence the mental condition of workers. Higher ethical standards within organization boost sense of moral obligations and their fulfillment in performing professional duties. Employees working in different Pakistani banks are inclined to observe higher moral and ethical standards due to the nature of their work environment and financial responsibility. Thus, organizational leaders are required to reflect high moral standards which help in creating an ethical work environment and consequently employees are less likely to quit their job.

In sum, the findings of this study directly feed banking organizations in Pakistan to maintain fairness in reward allocations to generate positive perceptions of banking staff and reduce their intention to leave organization. Furthermore, ethical style of leaders exhibiting high moral values will develop an ethical climate that also leads to reduced turnover intention of employees and effectively contributes to the accomplishment of organizational goals.

\subsection{Limitation and Future Recommendations}

The present study has some limitations due to smaller sample size and specific organizational context of banking sector in which respondents provided their feedback. Further studies with broader context of industrial and organizational environment may provide comprehensive understanding and generalized concept. Moreover, a larger sample size may also be helpful for more productive outcomes. Due to the constraints, a small number of organizations within a limited geographic region were approached for this study which may also limits the impact of findings. Thus, future studies should consider multiple organizational settings in different geographic areas for better output. Moreover, other contextual variables like cultural and environmental climates may also be included in future empirical investigations for valuable contribution.

\section{References}

[1] Adams, J. S. (1965). Inequity in social exchange. Advances in experimental social psychology, 2(267-299).

[2] Ahmed, P. K., \& Machold, S. (2004). The quality and ethics connection: toward virtuous organizations. Total Quality Management \& Business Excellence, 15(4), 527-545.

[3] Al Afari, T. S., \& Elanain, H. M. A. (2014). Procedural and distributive justice as mediators of the relationship between interactional justice and work outcomes: An empirical study of the UAE public health care sector. Journal of Applied Business Research, 30(4), 1091.

[4] Ali, M., \& Saifullah, Z. (2014). Distributive and procedural justice as predictors of job satisfaction and organizational commitment: A case study of banking sector of Balochistan. commitment, 6(34).

[5] Alreck, P., \& Settle, R. (2004). The Survey Research. Handbook.(3 Ed.) New York: McGrow-Hill Irwin. 
[6] Alshammari, A., Almutairi, N. N., \& Thuwaini, S. F. (2015). Ethical leadership: The effect on employees. International Journal of Business and Management, 10(3), 108.

[7] Asrar-ul-Haq, M., \& Kuchinke, K. P. (2016). Impact of leadership styles on employees' attitude towards their leader and performance: Empirical evidence from Pakistani banks. Future Business Journal 2(1), 54-64.

[8] Bakri, N., \& Ali, N. (2015). The Impact of Organizational Justice on Turnover Intention of Bankers of KPK, Pakistan: The Mediator Role of Organizational Commitment. Asian Social Science, 11(21), p143.

[9] Bandura, A. (1977). Social learning theory Englewood Cliffs. In NJ: Prentice-Hall.

[10] Bilal, M., Rehman, M. M., \& Rehman, C. A. (2015). Causes of Employees turnover in banking sector of Pakistan.

[11] Bodla, M. A., \& Ali, H. (2012). Workplace spirituality: A spiritual audit of banking executives in Pakistan. African Journal of Busi ness Management, 6(11), 3888

[12] Brown, M. E. (2007). Misconceptions of Ethical Leadership:: How to Avoid Potential Pitfalls. Organizational Dynamics, 36(2), 140155.

[13] Brown, M. E., \& Treviño, L. K. (2006). Ethical leadership: A review and future directions. The leadership quarterly, 17(6), 595616.

[14] Brown, M. E., Treviño, L. K., \& Harrison, D. A. (2005). Ethical leadership: A social learning perspective for construct development and testing. Organizational behavior and human decision processes 97(2), 117-134.

[15] Buble, M. (2012). Interdependence of organizational culture and leadership styles in large firms. Management: Journal of Contemporary Management Issues, 17(2), 85-97.

[16] Colquitt, J. A. (2001). On the dimensionality of organizational justice: a construct validation of a measure. Journal of applied psychology, 86(3), 386

[17] CompData, S. (2015-16). Employer-reported turnover rates by Industry 2015

[18] Cullen, J. B., Parboteeah, K. P., \& Victor, B. (2003). The effects of ethical climates on organizational commitment: A two-study analysis. Journal of Business Ethics, 46(2), 127-141.

[19] Davidovitz, R., Mikulincer, M., Shaver, P. R., Izsak, R., \& Popper, M. (2007). Leaders as attachment figures: leaders' attachment orientations predict leadership-related mental representations and followers' performance and mental health. Journal of Personality and social Psychology, 93(4), 632.

[20] DeConinck, J. B. (2015). Outcomes of ethical leadership among salespeople. Journal of Business Research, 68(5), 1086-1093.

[21] Demirtas, O., \& Akdogan, A. A. (2015). The effect of ethical leadership behavior on ethical climate, turnover intention, and affective commitment. Journal of Business Ethics, 130(1), 59-67.

[22] Dickson, M. W., Smith, D. B., Grojean, M. W., \& Ehrhart, M. (2001). An organizational climate regarding ethics: The outcome of leader values and the practices that reflect them. The leadership quarterly, 12(2), 197-217.

[23] Elçi, M., Şener, İ., Aksoy, S., \& Alpkan, L. (2012). The impact of ethical leadership and leadership effectiveness on employees' turnover intention: The mediating role of work related stress. ProcediaSocial and Behavioral Sciences, 58, 289-297.

[24] Eubanks, D. L., Brown, A. D., \& Ybema, S. (2012). Leadership, identity, and ethics. Journal of Business Ethics, 107(1), 1-3.

[25] Ferrell, O. C., \& Gresham, L. G. (1985). A contingency framework for understanding ethical decision making in marketing. The Journal of Marketing, 87-96.

[26] Flynn, G. (2008). The virtuous manager: A vision for leadership in business. In Leadership and Business Ethics (pp. 39-56): Springer.

[27] Hair, J. F., Black, W. C., Babin, B. J., Anderson, R. E., \& Tatham, R. L. (2006). Multivariate data analysis (Vol. 6): Pearson Prentice Hall Upper Saddle River, NJ.

[28] Hassan, A. (2002). Organizational justice as a determinant of organizational commitment and intention to leave. Asian Academy of Management Journal, 7(2), 55-66.

[29] Holtom, B. C., Mitchell, T. R., Lee, T. W., \& Inderrieden, E. J. (2005). Shocks as causes of turnover: What they are and how organizations can manage them. HUMAN RESOURCE MANAGEMENT-ANN ARBOR-, 44(3), 337.

[30] Hu, L. t., \& Bentler, P. M. (1999). Cutoff criteria for fit indexes in covariance structure analysis: Conventional criteria versus new alternatives. Structural equation modeling: a multidisciplinary journal, 6(1), 1-55.

[31] Hunjra, A. I., Chani, M. I., Aslam, S., Azam, M., \& Rehman, K. U. (2010). Factors effecting job satisfaction of employees in Pakistan banking sector. African Journal of Business Management, 4(10), 2157-2163.

[32] Khan, K., Abbas, M., Gul, A., \& Raja, U. (2013). Organizational justice and job outcomes: Moderating role of Islamic Work Ethic. Journal of Business Ethics, 126(2), 235-246.

[33] Kim, W. G., \& Brymer, R. A. (2011). The effects of ethical leadership on manager job satisfaction, commitment, behavioral outcomes, and firm performance. International Journal of Hospitality Management, 30(4), 1020-1026.

[34] Küçükbayrak, R. (2010). An integrative model of transformational leadership, organizational commitment, job satisfaction and organizational citizenship behavior. Unpublished Master Thesis, Middle East Technical University, Ankara.

[35] Kuntz, J., Kuntz, J., Elenkov, D., \& Nabirukhina, A. (2013). Characterizing ethical cases: A cross-cultural investigation of individual differences, organisational climate, and leadership on ethical decision-making. Journal of Business Ethics, 113(2), 317-331.

[36] Leventhal, G. S. (1980). What should be done with equity theory? : Springer.

[37] Loi, R., Hang-Yue, N., \& Foley, S. (2006). Linking employees' justice perceptions to organizational commitment and intention to leave: The mediating role of perceived organizational support Journal of Occupational and Organizational Psychology, 79(1), 101-120.

[38] Macklin, R., Martin, A., \& Mathison, K. (2014). An Integrated Model of Justice and Ethical Climates and the Influence of Cultural Diversity. 公正和道德气氛的一体化模式及文化多样性的影响. Management and Organization Review.

[39] Newman, K. L. (1993). Just Organization: Creating and Maintaining Justice in Work Environments, The. Wash. \& Lee L. Rev., 50, 1489.

[40] Niehoff, B. P., \& Moorman, R. H. (1993). Justice as a mediator of the relationship between methods of monitoring and organizational citizenship behavior. Academy of Management journal, 36(3), 527 556.

[41] Peterson, D. K. (2002). Deviant workplace behavior and the organization's ethical climate. Journal of business and psychology, 17(1), 47-61.

[42] Poon, J. M. (2012). Distributive Justice, Procedural Justice, Affective Commitment, and Turnover Intention: A MediationModeration Framework1. Journal of Applied Social Psychology, 42(6), 1505-1532.

[43] Ramay, I. M. (2012). Antecedents of organizational commitment of banking sector employees in Pakistan. Serbian Journal of Management, 7(1), 89-102.

[44] Schneider, B. (1975). Organizational climates: An essay. Personnel psychology, 28(4), 447-479.

[45] Shin, Y. (2012). CEO ethical leadership, ethical climate, climate strength, and collective organizational citizenship behavior. Journal of Business Ethics, 108(3), 299-312.

[46] Tett, R. P., \& Meyer, J. P. (1993). Job satisfaction, organizational commitment, turnover intention, and turnover: path analyses based on meta-analytic findings. Personnel psychology, 46(2), 259-293.

[47] Treviño, L. K., \& Weaver, G. R. (2001). Organizational justice and ethics program" follow-through": Influences on employees' harmful and helpful behavior. Business Ethics Quarterly, 651-671.

[48] Victor, B., \& Cullen, J. B. (1988). The organizational bases of ethical work climates. Administrative Science Quarterly, 101-125.

[49] Wang, Y.-D., \& Hsieh, H.-H. (2012). Toward a better understanding of the link between ethical climate and job satisfaction: A multilevel analysis. Journal of Business Ethics, 105(4), 535-545.

[50] Yin-Fah, B. C., Foon, Y. S., Chee-Leong, L., \& Osman, S. (2010). An exploratory study on turnover intention among private sector employees. International Journal of Business and Management, $5(8), \mathrm{p} 57$. 